\title{
Do birds disperse mosses? Evidence of endozoochory in upland geese Chloephaga picta and white-bellied seedsnipes Attagis malouinus in sub-Antarctic Chile
}

\author{
Xenabeth Lazaro ${ }^{1}$, Roy Mackenzie ${ }^{2}$, and Jaime Jimènez ${ }^{3}$ \\ ${ }^{1}$ University of Florida \\ ${ }^{2}$ Universidad de Magallanes \\ ${ }^{3}$ University of North Texas
}

March 2, 2021

\begin{abstract}
Birds are known to act as potential vectors for the exogenous dispersal of bryophyte diaspores. Given the totipotency of vegetative tissue of many bryophytes, birds could also contribute to endozoochorous bryophyte dispersal. Research has shown that fecal samples of the upland goose (Chloephaga picta) and white-bellied seedsnipe (Attagis malouinus) contain bryophyte fragments. Although few fragments from bird feces have been known to regenerate, the evidence for the viability of diaspores following passage through the bird intestinal tract remains ambiguous. We evaluated the role of endozoochory in these same herbivorous and sympatric bird species in sub-Antarctic Chile. We hypothesized that fragments of bryophyte gametophytes retrieved from their feces are viable and capable of regenerating new plant tissue. Eleven feces disc samples containing undetermined moss fragments from $C$. picta $(N=6)$ and A. malouinus $(N=5)$ and six moss fragment samples from wild collected mosses (Conostomum tetragonum, Syntrichia robusta, and Polytrichum strictum) were grown ex situ in peat soil and in vitro using a agar-Gamborg medium. After 91 days, $20 \%$ of fragments from A. malouinus feces, $50 \%$ of fragments from C. picta feces, and $67 \%$ of propagules from wild mosses produced new growth. The fact that moss diaspores remained viable and can regenerate under experimental conditions following the passage through the intestinal tracts of these robust fliers and altitudinal and latitudinal migrants, suggests that sub-Antarctic birds may play a critical role in bryophyte dispersal. This relationship may have important implications in the way bryophytes disperse and colonize habitats facing climate change. Keywords: birds, bryophyte dispersal, endozoochory, mosses, sub-Antarctic
\end{abstract}

Do birds disperse mosses? Evidence of endozoochory in upland geese Chloephaga picta and white-bellied seedsnipes Attagis malouinus in sub-Antarctic Chile

Xenabeth A. Lázaro ${ }^{1}$, Roy Mackenzie ${ }^{2}$, Jaime E. Jiménez ${ }^{3}$

${ }^{1}$ Department of Wildlife Ecology and Conservation, University of Florida, Gainesville, Florida, USA

${ }^{2}$ Sub-Antarctic Biocultural Conservation Program, Universidad de Magallanes, Punta Arenas, Chile

${ }^{3}$ Department of Biological Sciences and Advanced Environmental Research Institute, University of North Texas, Denton, Texas, USA

Corresponding Author:

Xenabeth Lázaro ${ }^{1}$

3190 SW 23rd ST, Miami, Florida, 33145, USA

Email address: xena.a.lazaro3867@gmail.com 


\begin{abstract}
Birds are known to act as potential vectors for the exogenous dispersal of bryophyte diaspores. Given the totipotency of vegetative tissue of many bryophytes, birds could also contribute to endozoochorous bryophyte dispersal. Research has shown that fecal samples of the upland goose (Chloephaga picta) and white-bellied seedsnipe (Attagis malouinus ) contain bryophyte fragments. Although few fragments from bird feces have been known to regenerate, the evidence for the viability of diaspores following passage through the bird intestinal tract remains ambiguous. We evaluated the role of endozoochory in these same herbivorous and sympatric bird species in sub-Antarctic Chile. We hypothesized that fragments of bryophyte gametophytes retrieved from their feces are viable and capable of regenerating new plant tissue. Eleven feces disc samples containing undetermined moss fragments from C. picta $(N=6)$ and A. malouinus $(N=5)$ and six moss fragment samples from wild collected mosses (Conostomum tetragonum, Syntrichia robusta, and Polytrichum strictum ) were grown ex situ in peat soil and in vitro using a agar-Gamborg medium. After 91 days, $20 \%$ of fragments from A. malouinus feces, $50 \%$ of fragments from C. picta feces, and $67 \%$ of propagules from wild mosses produced new growth. The fact that moss diaspores remained viable and can regenerate under experimental conditions following the passage through the intestinal tracts of these robust fliers and altitudinal and latitudinal migrants, suggests that sub-Antarctic birds may play a
\end{abstract}

critical role in bryophyte dispersal. This relationship may have important implications in the way bryophytes disperse and colonize habitats facing climate change.

Keywords : birds, bryophyte dispersal, endozoochory, mosses, sub-Antarctic

\title{
Cover Letter
}

We are excited to submit our manuscript "Do birds disperse mosses? Evidence of endozoochory in upland geese Chloephaga picta and white-bellied seedsnipes Attagis malouinus in sub-Antarctic Chile" to be considered for its publication in Ecology and Evolution.

This is an experimental research that addresses a potential novel mechanism for the dispersal of mosses. We investigated the ability of mosses to establish a new individual after being ingested by herbivorous birds, moving through their digestive system and being deposited in the feces on the ground by these wild birds.

We tested the idea that mosses can be dispersed through endozoochory by birds. We examined the content of feces of white-belied seedsnipes (Attagis malouinus) and of sympatric upland geese (Chloephaga picta) and cultivated the fragments of mosses found in the feces on two different substrates. We concurrently evaluated the viability of moss fragments from mosses collected from the same sites, in the far south of Chile. The fact that we obtained protonemas from wild moss fragments indicated the totipotency of the mosses. Further, the regeneration of bird-ingested mosses by both bird species indicated that birds defecate viable mosses that can produce new individuals.

This is a novel finding, especially considering that these are strong flying migratory birds that defecate in like substrates as where the mosses are found. Thus far, the paradigm for moss dispersal has been through wind and rain. We report that birds serve as biotic vectors through endozoochory and therefore may disperse mosses in ways and into places that the abiotic factors cannot. In the context to climate change and the "reshuffling" of biotic communities, this is especially important.

We consider that this paper presents convincing evidence that points out to a paradigm shift in moss dispersal that is prevalent and likely occurs in many other regions of the world. Hence, this research is in line with the aims of Ecology and Evolution in furthering our understanding of natural processes and that would interest a broad audience of readers.

\section{Introduction}

Bryophytes are considered the descendants of the earliest forms of plants on Earth and are found anywhere from the tundra to the tropical rainforest. However, they are typically associated with temperate forests, peatlands, tundra, and alpine regions (Goffinet et al., 2012). With climate change as a growing concern for 
high-elevation and high-latitude habitats, and the large proportion of bryophyte endemism in high latitude regions (Rozzi et al., 2008), it is important to understand the dispersal mechanisms and potential for bryophytes to colonize new habitats. According to Urban (2015), if the Earth's temperature increases by $3{ }^{\circ} \mathrm{C}$, South America will be one of three regions where extinction risks of species will be highest (23\%), followed by Australia and New Zealand (14\%). Additionally, climate change is causing an upslope shift in montane plant and animal communities (Elsen \& Tingley, 2015; Freeman et al., 2018) that is driven by niche conservatism, which is the retention of ancestral ecological characteristics, such as a habitat, by a species. Faced by climate change, species are more likely to respond by "following" their niches or ancestral climate regime rather than adapting their climatic tolerances (Wiens \& Graham, 2005), which may represent a challenge for sessile organisms such as mosses.

The ability of bryophytes to disperse and establish in new areas is fundamental to their survival in a changing planet. This is made possible through anemophily, or wind dispersal facilitated by sexual reproduction morphological features such as exposed spores, tall sporophytes, or the production of a large number of spores (Muñoz, 2004; Barbé et al., 2016), or via water, such as gemma or splash cups (Glime, 2017a; Glime, 2017b; Zanatta et al., 2018). Some species, like Tayloria dubyi, have even been known to have sticky spores and brightly colored sporophytes, that emit a strong odor, mimicking decomposing organic matter, to attract flies as potential dispersal vectors (Jofre et al., 2011). Bryophyte dispersal and colonization is also facilitated by bryophyte cell totipotency, an asexual reproduction mechanism able to regrow the entire gametophyte from tissue fragments (Anderson, 1963; Longton, 1997; Cleavitt, 2002; Proctor et al., 2007; Zhang et al., 2003). However, because some birds and bryophytes share the same habitats, these birds may serve as animal vectors that allow these small plants to reach areas that they would not reach otherwise, or help reach them quicker. The behavior of birds can aid in directed and long-distance movement of bryophytes as they may act as dispersers in local sites through foraging and nesting (Calvelo et al., 2006; Parnikoza et al., 2012; Amélio et al., 2017; Parnikoza et al., 2018), and transcontinentally through migratory movements (Chmielewski \& Eppley, 2019). Birds can disperse bryophytes long distances via ectozoochory, by external transportation (Lewis et al., 2014), and may be able to do this via endozoochory, through internal ingestion, as has also been shown with ferns and other herbs (Lovas-Kiss et al., 2018; Blanco et al., 2019; Hervías-Parejo et al., 2019; Silva et al., 2020).

The upland goose (Chloephaga picta, order Anseriformes, family Anatidae (Carboneras \& Kirwan, 2020)) and the white-bellied seedsnipe (Attagis malouinus, order Charadriiformes, family Thinocoridae (del Hoyo et al., 1996)) are two herbivorous bird species that inhabit sub-Antarctic South America and could be potential vectors for bryophyte dispersal. A. malouinus is an altitudinal migratory shorebird that moves downwards from its upland habitats to lowland flats during the harsh winters (Fjeldsa \& Krabbe, 1990; del Hoyo et al., 1996; Jaramillo et al., 2003; "e-Bird: White-bellied Seedsnipe Attagis malouinus ", n.d.) and has occasionally been known to leave Patagonia to the Falkland Islands (Hayman et al., 1986). C. picta is a migratory goose that is known to have larger movements through South America, migrating between breeding and wintering grounds. Pedrana et al. (2015) tracked the migratory route of a male C. picta and found that he migrated a minimum distance of $1485 \mathrm{~km}$ from Buenos Aires (the wintering grounds) to Santa Cruz province, Patagonia (the breeding grounds). This species also migrates altitudinally, as the same study found that the individual moved to lower than 100 masl on the wintering ground and between 1000-1500 masl on the breeding ground. Upland geese tagged on Navarino Island have been observed some $400 \mathrm{~km}$ north near Rio Gallegos in Argentina and some geese perform daily altitudinal migration from sea level up to over 700 masl there (J. Jiménez, 2020, pers. comm.).

Previous research suggests that birds, such as mallard ducks (Anas platyrhynchos) and sub-Antarctic geese and shorebirds, might be capable of dispersing bryophytes through endozoochory (Wilkinson et al., 2017; Russo et al., 2020). Additional evidence of bryophyte dispersal through endozoochory has been reported in spectacled flying foxes (Pteropus conspicillatus) (Parsons et al., 2007) and freshwater fish (Boedeltje et al., 2019). To our knowledge, the first observations of the consumption of bryophytes by C. picta and A. malouinus in sub-Antarctic South America were made by Behling et al. (2016). More recently, Russo et al. (2020) observed that fecal samples collected on a drying snowmelt bed were comprised of about 50- 
$80 \%$ sporophyte fragments from the moss family Polytrichaceae, and those collected on flooded meadows were comprised of about $80-100 \%$ bryophyte sporophytes. Of all fecal samples the authors uncovered, $91 \%$ of C. picta and $85 \%$ of A. malouinus samples contained bryophyte fragments, including fragments identified asPolytrichum sp., with at least one generating new growth.

Even though viable bryophyte gametophyte fragments have been recovered from avian species that feed on these plants, previous research has attempted to cultivate or regenerate these fragments with little success (Parsons et al., 2007; Wilkinson et al., 2017; Russo et al., 2020). Given that the dispersal and establishment of plants involves sequential and interdependent steps to be successful under field conditions, it is inappropriate to assume that finding bryophyte fragments in bird feces is directly correlated with successful dispersal. Thus, we cannot conclude that these fragments successfully propagate after passing through the bird's digestive system. For these reasons, together with the search of viable fragments in bird feces, it was necessary to first test if the bryophyte fragments found in bird feces were capable of regenerating when grown under lab conditions. Here, we make observations of the potential role of two herbivorous bird species, C. pictaand A. malouinus, as endozoochorous bryophyte dispersers by testing the viability and regenerative capabilities of fragmented bryophyte gametophytes retrieved from their feces. We propose that both avian species have the potential to serve as dispersal vectors for bryophytes in the sub-Antarctic through endozoochory. Our prediction is that after being ingested, defecated and cultivated under the proper conditions, the bryophyte fragments will have the totipotence to regenerate a new individual. Endozoochory is likely to be a widespread phenomenon. Therefore, our findings could be applicable to regions beyond sub-Antarctic Chile, like the Arctic, where birds also feed on mosses (Fox \& Bergersen, 2005) and climate change is altering the vegetation communities and plant-herbivore relations (Klein et al., 2008; Bjorkman et al., 2018).

\section{Materials \& Methods}

The research was conducted on Navarino Island $\left(54^{\circ} \mathrm{S}, 67^{\circ} \mathrm{W}\right)$, Magellanic region in sub-Antarctic Chile, at the southern end of the Americas. The island has a rugged topography with marked, but still moderate seasons. At the lower ranges, the forest is covered by a mix of southern beech species (Nothofagus betuloides and Nothofagus pumilio ) growing in krummholz formation at the tree line. Above the tree line, a rich community of small plants, including cushion plants, some graminoids, lichens and mosses, thrive in a Magellanic tundra environment (Méndez et al., 2013). We sampled C. pictafeces at sea level and C. picta and A. malouinus feces at ca. 700 masl, in open meadows some $100 \mathrm{~m}$ above the tree line. Field and laboratory work were conducted over the course of five weeks and the growth of recovered fragments was monitored over an additional 13 weeks in a growth chamber in Navarino Island, from December 2018 to April 2019.

In the field, fresh C. picta and A. malouinus fecal samples were collected from six locations, focusing on upland and lowland sites. We sampled opportunistically two sites near sea level, Lake Zañartu (19F 587064.87E 3911888.71S) and Robalo Bay (19F 585969.41E 3911044.12S), and four sites above the tree line, near streams and large ponds on the Cerro Bandera summit (19F 587490.15E 3908430.45S,19F 586779.97E 3907237.18S, 19F 586790.75E 3907270.36S). Fecal samples of both birds were identified in the field through our personal experience observing these birds in situ. Multiple fecal samples that visibly contained bryophyte fragments were collected from each site and later only one was selected from each site for processing $(n=6)$, three from each bird species. Of those six samples, there were two $C$. picta feces from lowland sites, one $C$. picta feces from an upland site, and three A. malouinus feces from upland sites. Additionally, mosses from three families (Polytrichum strictum, Brid., family Polytrichaceae, also known as "pigeon wheat"; Syntrichia robusta (Hook. \& Grev.) R.H. Zander, family Pottiaceae; and Conostomum tetragonum (Hedw.) Lindb., family Bartramiaceae), were sampled near fecal sample sites to test for regeneration capabilities compared to fragments from fecal samples under the same growing conditions. Bryophytes collected in the field were identified by RM using the preliminary key to mosses of Isla Navarino (Buck \& Goffinet, 2010).

In the laboratory, C. picta and A. malouinus fecal samples were stored in paper bags at room temperature before processing. We used a disinfected precision knife to remove the outer layer of the feces to eliminate the possibility of contamination by wind- or soil-borne spores and fragments. Two thin discs were then sliced from each fecal sample (approximately $1 \mathrm{~mm}$ in thickness). Each disc was dissolved separately in clear dishes 
using filtered water collected from the Robalo River (0.22- $\mu \mathrm{m}$ PVDF sterile syringe filters, Millipore, Cork, Ireland). The disc contents were observed under a Leica ICC50 HD compound microscope at 40x and 100x magnification. As many bryophyte fragments as possible were picked out from the dishes using a probe and forceps, placed into Eppendorf tubes corresponding to each disc sample and partially filled with filtered river water, following Russo et al.'s (2020) protocol. These samples were stored for a few days at $4^{\circ} \mathrm{C}$ until inoculation. Additionally, the wild collected mosses sampled were also cut into fragments.

The six fecal samples (three from each bird species) resulted in 11 disc samples analyzed, and 138 bryophyte fragments recovered and inoculated (106 belonging to C. picta and 32 to A. malouinussamples). The treatments tested were either a culture container, two plastic cups sealed together at the openings with parafilm, with commercial sterile peat soil (Kekkilä Professional Substrate) or a microplate for in vitro growth. The in vitro treatment was made using an agar-Gamborg Mixture Basal Salt (B5 salts) medium (G768, Phytotechnology Laboratories) with a $\mathrm{pH}$ of 5.8, a specific medium for moss growth (González et al., 2006). Once all fecal samples were processed, we randomly assigned the fragments from each fecal disc sample and from each moss species sample to either treatment to be propagated, with the exception of one A. malouinus sample, which only had one disc that contained one bryophyte fragment, and was therefore placed only in the agar-Gamborg treatment. For the peat soil treatment, the fragments were placed on the soil, thoroughly misted with filtered water and then covered and sealed for the remainder of the experiment with occasional misting throughout the observation period to keep the culture containers humid. High inner humidity and condensation was observed in the sealed containers throughout the experiment. For the agar-Gamborg treatment, the samples were placed in a 28-well agar plate and then covered and sealed with parafilm. A total of 18 culture mediums were placed into a growth chamber, with the temperature fluctuating between a minimum of $5{ }^{\circ} \mathrm{C}$ and maximum of $25{ }^{\circ} \mathrm{C}$ throughout the entirety of the experiment. Bryophyte cultures were grown on red and blue LED lights in a 4:1 ratio, at a day:night cycle of 16:8 h. The wild moss sample fragments inoculated in the peat soil containers were placed in the growth chamber on January $8^{\text {th }}, 2019$, followed by the fecal sample fragments inoculated in the peat soil containers on January $9^{\text {th }}$, 2019, and fecal sample and wild moss sample fragments inoculated in the agar-Gamborg on January $11^{\text {th }}$, 2019. All the samples were left in the growth chamber for a total of 91 days.

\section{Results and Discussion}

A total of 8 culture mediums of $18(44 \%)$ produced growth in the treatments tested. One of five culture mediums with A. malouinusfragment samples (20\%), three of six with C. picta fragment samples (50\%), and four of six with wild moss fragment samples (67\%) produced new growth (Table 1) based on the occurrence of light-colored green shoots and moss beds (Figure 1). Five of the nine (56\%) fecal fragment inoculations treated to the peat soil treatment (three from C. picta, one from A. malouinus, and one fromPolytrichum sp. ) and all three (100\%) inoculations of fragmented wild mosses in the solid agar-Gamborg medium showed vegetative growth. On the contrary, no growth was observed in the agar-Gamborg for any of the six inoculations tested from the feces of both bird species.

Previous research has attempted to cultivate fragments found in fecesin vitro with some success (Wilkinson et al., 2017; Russo et al., 2020). In this study, we partially followed Russo et al.'s (2020) fragment-processing methods. However, we decided to set two growing conditions for the fragments recovered from the feces to increase the probability of bryophyte growth. These consisted of anex situ growth condition using commercial peat soil, and anin vitro condition using agar-Gamborg medium for both fragments from fecal and wild moss samples taken from the field. We predicted that the fragments from both wild moss and fecal samples would regenerate. Previous research described growth from bryophyte spores after 60 days (Proctor, 1961) and from bryophyte fragments after 11 days (Wilkinson et al., 2017). However, we did not observe signs of regeneration from our cultures until 42 days of growth.

Our reasoning for the chosen treatments was to test which, if any, would allow bryophyte fragment recovery and growth under lab conditions. Although the sample size was small, we observed clear evidence of bryophyte regeneration from feces of both bird species in the peat soil treatment (see Table 1). These results reveal that a small fraction of moss diaspores remains viable following the passage through the intestinal tract of both 
birds and is capable of regeneration in suitable conditions. Although small, our cases are significant. Given the volume of the feces and the number of feces defecated daily by each bird, if our results were multiplied by the number of birds per area and time, our results would translate into a large absolute number. Additionally, the growth evidence observed in the three wild mosses in the agar-Gamborg confirmed that the bryophytes sampled are totipotent, which is a necessary condition for effective endozoochory mechanisms.

It is plausible that the in vitro (agar-Gamborg) conditions could have yielded false negative results from the fecal sample fragments tested of both bird species (see Table 1), as moss diaspores may take longer to germinate in sterile conditions due to the necessary acclimation to the agar-Gamborg substrate and neutral pH conditions in the medium (Sabovljevic et al., 2014). However, there was evidence of bryophyte regeneration in fragments recovered from feces in the peat soil substrate. On the other hand, wild moss gametophyte growth was observed in samples inoculated both in agar-Gamborg medium and peat soil. Therefore, these results support the hypothesis of bird endozoochory of these bryophytes in the sub-Antarctic environment.

\section{Conclusions}

We confirmed the hypothesis that fragmented bryophyte gametophytes retrieved from the feces of herbivorous birds could regenerate in laboratory conditions. Consequently, our research shows that it is plausible for fragments to be dispersed through endozoochory by these herbivorous birds in the sub-Antarctic, possibly further aiding bryophytes in this region to disperse beyond wind or rain, and increasing their capability to reach specific habitat types (Figure 2). As both bird species are robust fliers, altitudinal migrants for short distances and latitudinal migrants for long distances, their role as dispersers might not only occur locally, but also at a broader scale. This is especially important as with warming conditions, organisms such as mosses would have to move to higher altitudes or latitudes to maintain viable populations. By serving as dispersal vectors, birds would be able to aid in this process in short time scales in the vertical and horizontal axes of the landscape. This process is especially critical in maintaining the viability of bryophytes in Navarino Island, which contains an "ecosystem of highest ecological importance" (Goffinet et al., 2012) and holds many endemic species (Méndez et al., 2013), and just as critical globally where bryophytes are also being affected by changes to their ecosystems.

Sub-Antarctic birds may play a passive, but likely critical role in the dispersal of bryophytes, as birds are more likely to defecate in like habitat conditions where they graze (J. Jiménez, 2019, pers. comm.). Thus, potentially enabling bryophytes to effectively propagate within a generally suitable habitat and in locations where they are unlikely to be established by wind or rain, but are accessible to birds. However, further research needs to be done to test bryophyte dispersal through endozoochory and the role of birds in this process. To progress along this line of research, we suggest a larger sample size and replication, more substrate treatments, as bryophyte fragments might respond variably to distinct types of soil, and conducting DNA sequencing of the bryophyte fragments found in the fecal samples to identify the bryophyte species before culturing them. Finally, there is the need to reproduce these results under field conditions, so we can understand the relevance of this type of zoochory in bryophyte dispersal at these high-latitude landscapes.

\section{References}

Amélio, L. D., Carmo, D. M., Lima, J. S., \& Peralta, D. F. (2017). Bryophytes as a material to build birds' nests in Brazil. Boletín de la Sociedad Argentina de Botánica, 52 (2), 199-208. doi:10.31055/1851.2372.v52.n2.17434.

Anderson, L. E. (1963). Mosses. The Bryologist, 66 (3), 107-119. doi:10.2307/3240710.

Barbé, M., Fenton, N. J., \& Bergeron, Y. (2016). So close and yet so far away: Long-distance dispersal events govern bryophyte metacommunity reassembly. Journal of Ecology, 104 (6), 1707-1719. doi:10.1111/13652745.12637 .

Behling, E., Caviness, T. E., Lewis, L. R., Jimenez, J. E., Goffinet, B., \& Rozzi, R. (2016). Dispersal of bryophyte diaspores following ingestion by birds. Conference Abstract 224. Botany 2016. Savannah, 
Georgia. July 30-August 3.

Bjorkman, A. D., Myers-Smith, I. H., Elmendorf, S. C., Normand, S., Ruger, N., Beck, P. S., . . . Weiher, E. (2018). Plant functional trait change across a warming tundra biome. Nature, 562 (7725), 57-62. doi:10.1038/s41586-018-0563-7.

Blanco, G., Bravo, C., Chamorro, D., Lovas-Kiss, A, Hiraldo, F., \& Tella, J. L. (2019). Herb endozoochory by cockatoos: Is 'foliage the fruit'? Austral Ecology, 45 (1), 122-126. doi:10.1111/aec.12835.

Boedeltje, G., Klutman, B., Schaap, M., Sollman, P., Vos, M., Lenssen, J. P. M., \& Verberk, W. C. E. P. (2019). Plant dispersal in a temperate stream by fish species with contrasting feeding habits: The role of plant traits, fish diet, season, and propagule availability. Frontiers in Ecology and Evolution, 7 (54), 1-15. doi:10.3389/fevo.2019.00054.

Buck, W. R. \& Goffinet, B. (2010). Preliminary key to the mosses of Isla Navarino, Chile (Prov. Antartica Chilena).Nova Hedwigia, Beiheft, 138 , 215-229.

Calvelo, S., Trejo, A., \& Ojeda, V. (2006). Botanical composition and structure of hummingbird nests in different habitats from northwestern Patagonia (Argentina). Journal of Natural History, 40 (9-10), 589-603. doi:10.1080/00222930500371000.

Carboneras, C., \& Kirwan, G. M. (2020). Upland Goose (Chloephaga picta), version 1.0. In Birds of the World (J. del Hoyo, A. Elliott, J. Sargatal, D. A. Christie, and E. de Juana, Editors). Cornell Lab of Ornithology, Ithaca, NY, USA. doi: 10.2173/bow.uplgoo1.01.

Chmielewski, M. W., \& Eppley, S. M. (2019). Forest passerines as a novel dispersal vector of viable bryophyte propagules. Proceedings of the Royal Society B: Biological Sciences, 286 (1897), 1-8. doi: 10.1098/rspb.2018.2253.

Cleavitt, N. L. (2002). Stress tolerance of rare and common moss species in relation to their occupied environments and asexual dispersal potential. Journal of Ecology, 90 (5), 785-795. doi: 10.1046/j.13652745.2002.00713.x.

del Hoyo, J. D., Elliott, A., \& Sargatal, J. (1996). Family Thinocoridae (Seedsnipes). In Handbook of the birds of the world(Vol. 3, pp. 538-545). Barcelona, Spain: Lynx Ediciones.

eBird. (n.d.). eBird: White-bellied Seedsnipe Attagis malouinus.eBird, Cornell Lab of Ornithology, Ithaca, New York. Available: https://ebird.org/species/whbsee2/AR-V. (Accessed: February 12, 2021).

Elsen, P. R., \& Tingley, M. W. (2015). Global mountain topography and the fate of montane species under climate change. Nature Climate Change, 5 (8), 772-776. doi: 10.1038/nclimate2656.

Fjeldsa, J., \& Krabbe, N. (1990). Birds of the high Andes . Copenhagen, Denmark: Zoological Museum, University of Copenhagen. pp. 876.

Fox, A. D., \& Bergersen, E. (2005). Lack of competition between barnacle geese Branta leucopsis and pinkfooted geese Anser brachyrhynchus during the pre-breeding period in Svalbard. Journal of Avian Biology, 36 (3), 173-178. doi:10.1111/j.0908-8857.2005.03540.x.

Freeman, B. G., Scholer, M. N., Ruiz-Gutierrez, V., \& Fitzpatrick, J. W. (2018). Climate change causes upslope shifts and mountaintop extirpations in a tropical bird community. Proceedings of the National Academy of Sciences, 115 (47), 11982-11987. doi: 10.1073/pnas.1804224115.

Glime, J.M. (2017a). Adaptive strategies: Spore dispersal vectors. Chapt. 4-9. In J. M. Glime, Bryophyte ecology (Vol. 1, pp. 1-43). Ebook sponsored by Michigan Technological University and the International Association of Bryologists. Last updated 3 June 2020 and available at $<$ http://digitalcommons.mtu.edu/bryophyte-ecology/>. (Accessed: July 23, 2020). 
Glime, J.M. (2017b). Adaptive strategies: Vegetative dispersal vectors. Chapt. 4-11. In J. M. Glime, Bryophyte ecology (Vol. 1, pp. 1-42). Ebook sponsored by Michigan Technological University and the International Association of Bryologists. Last updated 14 May 2020 and available at $<$ http://digitalcommons.mtu.edu/bryophyte-ecology/>. (Accessed: July 23, 2020).

Goffinet, B., Rozzi, R., Lewis, L., Buck, W., \& Massardo, F. (2012).Miniature forests of Cape Horn: Ecotourism with a hand lens. Bosques en miniatura del Cabo de Hornos: Ecoturismo con lupa. Denton, Texas: University of North Texas Press \& Punta Arenas, Chile: Ediciones Universidad de Magallanes. pp. 445.

Gonzalez, M.L., Mallon, R., Reinoso, J., \& Rodriguez-Oubina, J. (2006). In vitro micropropagation and long-term conservation of the endangered moss Splachnum ampullaceum . Biologia Plantarum, 50 (3), 339-345. doi: 10.1007/s10535-006-0047-8.

Hayman, P., Marchant, J., \& Prater, T. (1986). Shorebirds: An identification guide to waders of the world . London: Houghton Mifflin. pp. 412.

Hervias-Parejo, S., Olesen, J. M., Nogales, M., Traveset, A., \& Heleno, R. (2019). Dispersal of fern spores by Galapagos finches. Journal of Ornithology, 160 (3), 831-833. doi: 10.1007/s10336-019-01656-9.

Jaramillo, A., Burke, P., \& Beadle, D. (2003). Birds of Chile . London: Christopher Helm. pp. 288.

Jofre, J., Goffinet, B., Marino, P., Raguso, R. A., Nihei, S. S., Massardo, F., \& Rozzi, R. (2011). First evidence of insect attraction by a Southern Hemisphere Splachnaceae: The case of Tayloria dubyiBroth. in the Reserve Biosphere Cape Horn, Chile. Nova Hedwigia,92 (3), 317-326. doi: 10.1127/0029-5035/2011/00920317 .

Klein, D. R., Bruun, H. H., Lundgren, R., \& Philipp, M. (2008). Climate change influences on species interrelationships and distributions in high-Arctic Greenland. Advances in Ecological Research, 40 , 81-100. doi: 10.1016/S0065-2504(07)00004-9.

Lewis, L. R., Behling, E., Goussel, H., Qian, E., Elphick, C. S., Lamarre, J. F., Bety, J., Liebezeit, J., Rozzi, R., \& Goffinet, B. (2014). First evidence of bryophyte diaspores in the plumage of transequatorial migrant birds. PeerJ, 2, e424. doi: 10.7717/peerj.424.

Longton, R. E. (1997). Reproductive biology and life-history strategies.Advances in Bryology, 6 , 65-101.

Lovas-Kiss, A., Vizi, B., Vincze, O., Molnar, V. A., \& Green, A. J. (2018). Endozoochory of aquatic ferns and angiosperms by mallards in central Europe. Journal of Ecology, 00, 1-10. doi: 10.1111/1365-2745.12913.

Mendez, M., Rozzi, R., \& Cavieres, L. (2013). Flora vascular musgos en la zona altoandina de la Isla Navarino (55oS), Reserva de Biosfera Cabo de Hornos, Chile. Gayana Botanica, 70 (2), 337-343. doi:10.4067/s071766432013000200011.

Munoz, J. (2004). Wind as a long-distance dispersal vehicle in the Southern Hemisphere. Science, 304 (5674), 1144-1147. doi: 10.1126/science.1095210.

Parnikoza, I., Dykyy, I., Ivanets, V., Kozeretska, I., Kunakh, V., Rozhok, A., Ochyra, R., \& Convey, P. (2012). Use of Deschampsia antarctica for nest building by the kelp gull in the Argentine Islands area (maritime Antarctica) and its possible role in plant dispersal.Polar Biology, 35 (11), 1753-1758. doi: $10.1007 / \mathrm{s} 00300-012-1212-5$.

Parnikoza, I., Rozhok, A., Convey, P., Veselski, M., Esefeld, J., Ochyra, R., Mustafa, O., Braun, C., Peter, H. U., Smykla, J., Kunakh, V., \& Kozeretska, I. (2018). Spread of Antarctic vegetation by the kelp gull: Comparison of two maritime Antarctic regions. Polar Biology, 41 (6), 1143-1155. doi: 10.1007/s00300-0182274-9.

Parsons, J. G., Cairns, A., Johnson, C. N., Robson, S. K. A., Shilton, L. A., \& Westcot, D. A. (2007). Bryophyte dispersal by flying foxes: A novel discovery. Oecologia, 152 (1), 112-114. doi: 10.1007/s00442006-0639-1. 
Pedrana, J., Pon, J. P. S., Isacch, J. P., Leiss, A., Rojas, P. O., Castresana, G., Calvo, J., Bernad, L., Munoz, S. D., Maceira, N. O., \& Putz, K. (2015). First insights into the migration pattern of an upland goose (Chloephaga picta) based on satellite tracking. Ornitología Neotropical, 26 , 245-253.

Proctor, M. C. F., Oliver, M. J., Wood, A. J., Alpert, P., Stark, L. R., Cleavitt, N. L., \& Mishler, B. D. (2007). Desiccation-tolerance in bryophytes: A review. The Bryologist, 110 (4), 595-621. doi: 10.1639/00072745(2007)110[595:dibar]2.0.co;2.

Proctor, V. W. (1961). Dispersal of Riella spores by waterfowl.Bryologist, 64 (1), 58-61. doi: 10.2307/3240925.

Rozzi, R., Armesto, J. J., Goffinet, B., Buck, W., Massardo, F., Silander, J., Arroyo, M. T. K., Russell, S., Anderson, C. B., Cavieres, L. A., \& Callicott, J. B. (2008). Changing biodiversity conservation lenses: Insights from the Subantarctic non-vascular flora of southern South America. Frontiers in Ecology and the Environment, 6 (3),131-137. doi: 10.1890/070020.

Russo, N. J., Robertson, M., Mackenzie, R., Goffinet, B., Jiménez, J. E. (2020). Evidence of targeted consumption of mosses by birds in sub-Antarctic South America. Austral Ecology, 45 (3), 399-403. doi: 10.1111/aec.12858.

Sabovljevic, M., Vujicic, M., Pantovic, J., \& Sabovljevic, A. (2014). Bryophyte conservation biology: In vitro approach to the ex situ conservation of bryophytes from Europe. Plant Byosistems ,148 (4), 857-868. https://doi.org/10.1080/11263504.2014.949328

Silva, G. G., Green, A. J., Hoffmann, P., Weber, V., Stenert, C., Lovas-Kiss, A., \& Maltchik, L. (2020). Seed dispersal by neotropical waterfowl depends on bird species and seasonality. Freshwater Biology, 00 , 1-11. doi: $10.1111 /$ fwb.13615.

Urban, M. C. (2015). Accelerating extinction risk from climate change.Science, 348 (6234), 571-573. doi: $10.1126 /$ science.aaa4984.

Wiens, J. J., \& Graham, C. H. (2005). Niche conservatism: Integrating evolution, ecology, and conservation biology. Annual Review of Ecology, Evolution, and Systematics, 36 (1), 519-539. doi: 10.1146/annurev.ecolsys.36.102803.095431.

Wilkinson, D. M., Lovas-Kiss, A., Callaghan, D. A., \& Green, A. J. (2017). Endozoochory of large bryophyte fragments by waterbirds.Cryptogamie, Bryologie, 38 (2), 223-228. doi: 10.7872/cryb/v38.iss2.2017.223.

Zanatta, F., Vanderpoorten, A., Hedenäs, L., Johansson, V., Patiño, J., Lönnell, N., \& Hylander, K. (2018). Under which humidity conditions are moss spores released? A comparison between species with perfect and specialized peristomes. Ecology and Evolution, 00 , 1-8. doi: 10.1002/ece3.4579.

Zhang, L., Ma, P., Chu, L-M., But, \& PP-H. (2003). Three modes of asexual reproduction in the moss Octoblepharum albidum. Journal of Bryology, 25 (3), 175-179. doi: 10.1179/037366803235001751.

Figures \& Tables

Figure 1: Moss regeneration from bryophyte fragments.

Detailed image of green shoots and a moss bed that regenerated in the peat soil treatment from the bryophyte fragments extracted from an upland goose (Chloephaga picta) fecal sample.

Figure 2: Schematic diagram of native bryophyte endozoochory by sub-Antarctic birds.

Schematic illustration of the possible endozoochory mechanism of bryophyte dispersal by the upland goose (Chloephaga picta) and the white-bellied seedsnipe (Attagis malouinus).

Table 1: Summary of bryophyte regeneration results for each bird fecal and wild moss sample in each treatment. 
Growth results for fragments from feces and mosses $(N=17)$. Regeneration presence and absence of fragments recovered from upland goose (Chloephaga picta) and white-bellied seedsnipe (Attagis malouinus) feces and fragments of wild collected mosses (Syntrichia robusta, Polytrichum strictum, and Conostomum tetragonum ) grown under controlled light regimes and two types of substrates in a growth chamber.

\begin{tabular}{lll}
\hline Sample & Peat Soil & Agar-Gamborg \\
\hline Chloephaga feces 1 & + & - \\
Chloephaga feces 2 & + & - \\
Chloephaga feces 3 & + & - \\
Chloephaga TOTAL (\%) & $\mathbf{1 0 0}$ & $\mathbf{0}$ \\
Attagis feces 1 & - & - \\
Attagis feces 2 & $\mathrm{NA}$ & - \\
Attagis feces 3 & + & - \\
Attagis TOTAL (\%) & $\mathbf{5 0}$ & $\mathbf{0}$ \\
Syntrichia & - & + \\
Polytrichum & + & + \\
Conostomum & - & + \\
MOSS TOTAL (\%) & $\mathbf{3 3}$ & $\mathbf{1 0 0}$ \\
\hline
\end{tabular}

Symbols and acronyms for samples indicate Chloephaga: C. picta (upland goose); Attagis: A. malouinus (white-bellied seedsnipe); Syntrichia: S. robusta moss sample;Polytrichum: P. strictum moss sample; Conostomum: C. tetragonum moss sample; +: growth; -: no growth; NA: no sample in that combination.

\section{Data Accessibility}

The raw data used in the present study is publicly available in the Dryad repository.

\section{Competing Interests}

The authors declare no competing interests.

\section{Author Contributions}

X.A.L. executed the experiment, collected the data, and drafted the manuscript. R.M. analyzed the data. All authors contributed to the conceptualization, writing and editing of the manuscript.

\section{Acknowledgements}

This research was funded by the National Science Foundation - International Research Experience for Students (NSF-IRES 1658651), the project CONICYT-PAI N 79170119, the University of North Texas and University of Magallanes. We are grateful to Bernard Goffinet and Lily Lewis for advice and fruitful discussions on bryophyte research. Additionally, we would like to thank Elke Schüttler and Tamara Contador for project logistic support, Jonilee Polanco and Taylor Gillum for assistance in the collection of data, Nicholas Russo and Michael Robertson for addressing project-related inquiries, and Javiera Videla for the detailed pictures. 

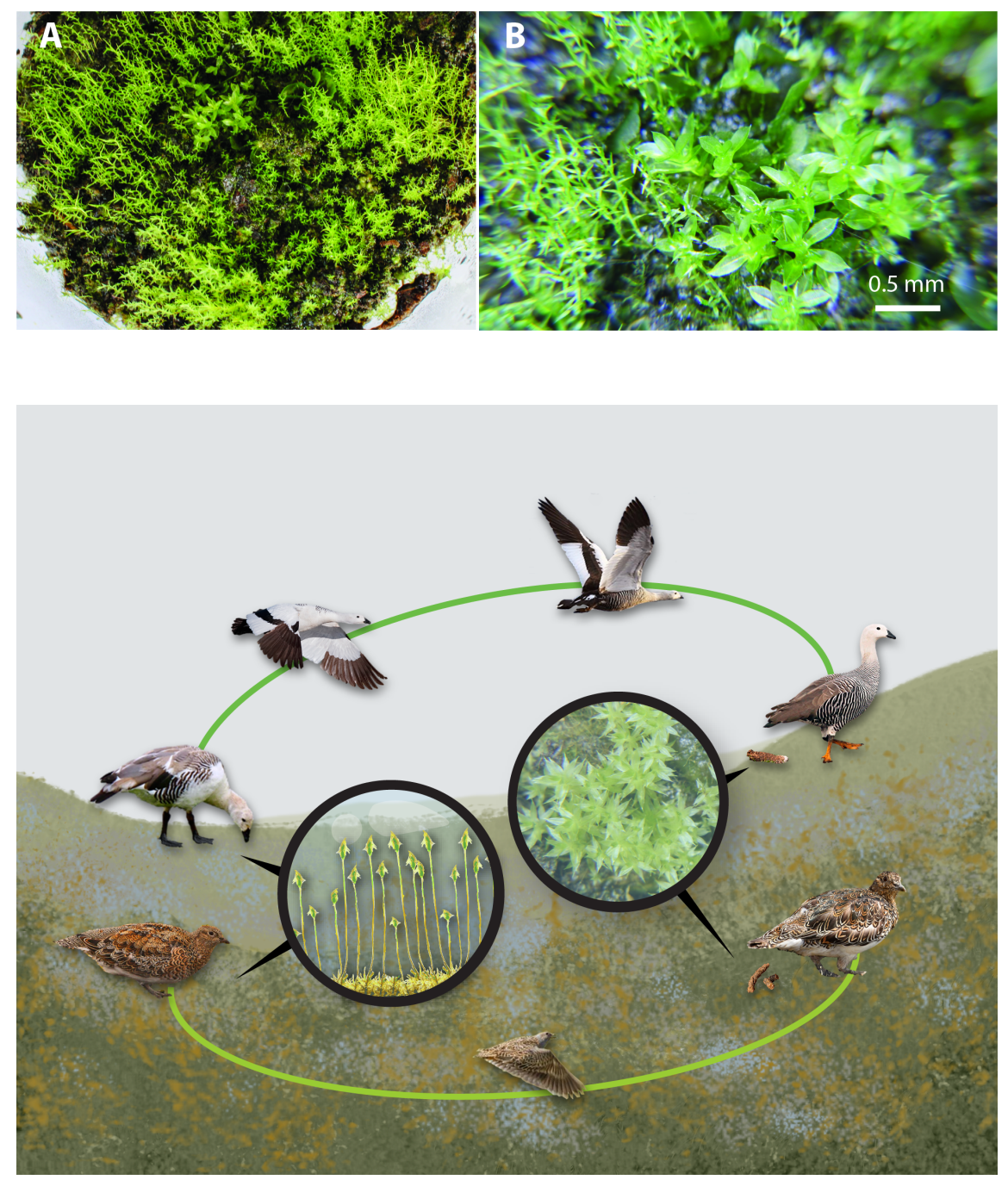